\title{
Politics of inclusion and exclusion in the Chinese Industrial Tree Plantation sector: the global resource rush seen from inside China
}

Yunan $\mathrm{Xu}$

International Institute of Social Studies, Erasmus University of Rotterdam, The Hague, The Netherlands

\author{
*Yunan $\mathrm{Xu}$ \\ International Institute of Social Studies \\ Erasmus University of Rotterdam \\ Kortenaerkade 12, \\ 2518 AX The Hague, \\ The Netherlands. \\ Email: xuyunancindy@gmail.com \\ Tel: +31644163188
}

Note: this is not the official version of the article. For the published version, please send an email toxuyunancindy@gmail.com to ask for a copy, or go for a download to:

http://www.tandfonline.com/doi/abs/10.1080/03066150.2017.1405936

\begin{abstract}
In the last two decades, the Industrial Tree Plantation (ITP) sector has expanded rapidly in southern China causing important changes in land-use and land control. It involves both domestic and transnational corporations, and has provoked widespread conflict and political contestations. The villagers who are affected by the expansion of ITPs have reacted in variegated and complex ways: some of the villagers were incorporated in the ITP sector, while others are excluded; some have embraced the change, while others have complaints; and some of the complaints remained latent, while others developed into (overt or covert) forms of resistance. This paper explores how and why various social groups have responded differently to the expansion of ITPs. This paper reveals the dynamics of villagers' inclusion and exclusion in the ITP sector, covering both 'passive' and 'active' forms of inclusion and exclusion, resulting in differentiated political reactions from villagers. This paper hopes to contribute towards a more comprehensive understanding of the complex engagement of villagers in changes in large-scale land-use and land control not just in the most commonly studied countries in global land grabbing - but inside China, and in land transactions that involved large foreign companies, something that has so far been missed in the literature on land grabbing.
\end{abstract}

Keywords: China, land grabbing, industrial tree plantations, resistance 


\section{Introduction}

In the past two decades, the Industrial Tree Plantation (ITP) sector has expanded rapidly in southern China's Guangxi Province, involving both domestic and foreign capital. In this paper, ITPs refer to monocultures of fast-growing tree crops mainly used for inedible industrial raw materials, including eucalyptus, pine, and acacia trees. Different from the definitions given by Overbeek (2012), Kröger (2014) and Gerber (2011), here ITPs not only refer to those large-scale forestry plantations owned/controlled by corporations, but also include large-scale individually-owned and small-scale villager-owned tree plantations. ${ }^{1}$ Among the fast-growing trees, eucalyptus has become the most popular in Guangxi, and is the focus of my study. There are many different scales of ITP cultivation in Guangxi, and most have been established on converted farmland and forestland. ${ }^{2}$ The rise of this sector has led to significant changes in land control, including the (re)transfer of land-based wealth and power from individuals, collectives or the state to various investors.

In Guangxi, the small-scale ITPs controlled by rural households and large-scale ITPs controlled by corporations and individuals coexist. ${ }^{3}$ The affected villagers face similar sociopolitical and ecological dynamics of the ITP expansion, yet they have reacted in variegated and complex ways: some of the villagers become incorporated into, while others are excluded from the ITP sector; some have embraced the change, while others have expressed opposition; and some of the grievances remained latent, while others developed into (overt or covert) forms of resistance. ${ }^{4}$ Why and how does the divergence among these affected villagers occur? And how do the socially differentiated villagers respond differently to the rise of the ITP sector in Guangxi?

Recent literature provides a rich analysis of the complicated trajectories of political reactions from below to land deals. In the literature, diverse forms of villagers' resistance are discussed, ranging from individual covert forms of everyday resistance (Moreda 2015), individual overt “rightful resistance”(O'Brien et al. 2006), and overt movements (Edelman 1999, Martiniello 2015), to more mixed and dynamic forms (McAllister 2015, Alonso-Fradejas 2015). In some cases, villagers sought different alliances during their resistance, with state actors or elites (Gingembre 2015), indigenous people (Brent 2015), and different NGOs (Rocheleau 2015). In some cases, instead of resisting, villagers chose to adapt (Mamonova 2015) or even welcome the changes in land-use and land control (Castellanos-Navarrete and Jansen 2015, Franco, Carranza, and Fernandez 2011). However, within existing literature on political reactions to land-use and land control change, there are still three gaps which (building on Hall et al. 2015 and Borras and Franco 2013), must be fully explored.

Firstly, recent literature is overly focused on villagers' resistance against corporations or the state, while intra- or inter-community conflicts along a "poor people versus poor people” axis

\footnotetext{
${ }^{1}$ In this paper, I use "villagers” to describe socially differentiated rural residents. These villagers are not the same as the "peasants" defined by Chayanov who only conduct subsistence farming. Most of the villagers are doing off-farm work. Meanwhile, they are not backward and low-quality as discoursed in the contemporary narratives of Chinese peasants (see Schneider 2015). They have their specific advantages. Moreover, some villagers are not purely "smallholders". Although villagers in China usually have small plots of land, during the past decade or so some have acquired more land than others (this will be analysed in the following sections).

${ }^{2}$ Here forestland is not necessarily natural forestry, but one of the eight land-uses classified by the Chinese government according to Land Management Law. In this case of Guangxi, according to Guangxi Tongzhi, most of the natural forests had been destroyed for food production or left with bushes and weeds before the rise of the ITP sector. Thus, such land-use change in Guangxi's forestland not necessarily lead to deforestation.

(Guangxi Forestry department, 1998).

${ }^{3}$ Among those individual-dominated large-scale ITPs, there are a few owned by some local villagers.

${ }^{4}$ It reveals that the political reactions from below towards the rise of the ITP sector in China is much more complex than the well-known stories told in the documentary Red Forest Hotel.
} 
have received less attention (Borras and Franco 2013, Borras, Franco, and Wang 2013, Hall et al. 2015), despite their prevalence. ${ }^{5}$ When faced with the expansion of the ITP sector, villagers not only resist, but are also resisted against.

Secondly, most land grabbing studies are overly centered on villagers' struggles around land access (e.g. against expulsion). Other triggers for political reactions from below, however, have not received significant attention. ${ }^{6}$ In reality, triggers for villagers' resistance are highly diverse. In Guangxi, a large part of the political reactions initiated by the villagers are not directly related to land control, but are struggles over levels of land rent or about the negative ecological impacts of the ITPs.

Thirdly, contemporary literature tends to focus mostly on the struggles of villagers (excluded from the land deals and/or the emerging enterprises), while the struggles of those who have been included in the emerging enterprises are rarely studied in any systematic ways. ${ }^{7}$ In Guangxi, villagers who are included in the ITP complex, especially into subordinate positions, have taken action to improve the terms of their incorporation, while some of the excluded villagers are indifferent to the rise of the ITP sector.

This set of literature misses part of the contours and trajectories of political reactions from below. As highlighted by Borras and Franco $(2013,1724)$ and Hall et al. (2015), villagers are not homogeneous groups. They have distinct resource endowments (e.g. land control, labour conditions, financial resources and social relations) and are embedded in certain politicaleconomic environments. Partly as a consequence of this, they are affected differently, causing them to have distinct interests. In regard to villagers' inclusion and exclusion, Hall et al. $(2011,15)$ identified four powers that shape the process of exclusion, mainly around land access, namely, "regulation, the market, force and legitimacy". Nevertheless, the conflicts are not always focused on land ownership and control. On the one hand, land access is not automatically and necessarily always empowering for villagers. In the case of soybean expansion in Bolivia, villagers who maintain their land access might still be vulnerable and are squeezed out by the market because they lack access to financial capital and technology. McKay and Colque (2016) call this "productive exclusion”. On the other hand, when villagers have profitable alternative sources of livelihood, land access or ITP inclusion is not their primary concern. In Guangxi, some villagers actively chose not to expand their land control and engage in the ITP sector, even when they had the resources to do so. For a better understanding of villagers' inclusion/ exclusion, the analysis should not be limited to land access, but should also focus on their positions within the broader "dynamics of change in social relations” (Borras and Franco 2013, 1741). Borras and Franco (2013) cautioned that the simple "exclusion versus inclusion" dichotomy cannot capture diverse (win/lose) outcomes for villagers and their varying political reactions. On the one hand, villagers who are excluded do not necessarily lose during the process. Rather, under certain conditions, "exclusion and separation can be valid strategies for the poor" (Du Toit 2004, 1004). On the other hand, villagers who are adversely incorporated might be left in a more vulnerable situation (Du Toit 2004, McCarthy 2010). Villagers who are excluded do not necessarily have grievances about changes in land-use and land control. Villagers who got incorporated might resist the terms of their incorporation. This complexity requires a broader exploration of the politics of inclusion/exclusion. When villagers engage in political reactions, they follow diverse trajectories involving different aims and actors. Some of the villagers'

\footnotetext{
${ }^{5}$ There have been some studies that point out the division among rural dwellers during land use and control changes (Gerber 2011, McElwee 2009, McElwee 2012),

${ }^{6}$ Although there have already been a few studies that have pointed out environmental conflicts over the ITP sector (Gerber 2011, Gerber and Veuthey 2010).

7 There used to be many studies about plantation workers' struggles for the improvement of their terms of inclusion. However, the current focus in academia has been shifted to the struggles of the excluded.
} 
resistance can be seen as "struggles against expulsion", while some are "struggles for, and within incorporation” (Borras and Franco 2013, 1731). Thus, villagers' struggles should be understood in a relational and dynamic way, considering their distinct demands during landuse and land control changes.

Based on the above discussion, this paper analyzes the dynamics of villagers' different political reactions. It focuses particularly on the varying and/or competing interests among villagers based on their different linkages with the sector (namely, 'passive' or 'active' inclusion, and 'active' or 'passive' exclusion), and related gains and losses. By doing this, this paper does not intend to argue that the dynamics of conflicts over the expansion of ITPs in Guangxi are different from or similar to those occurred in other countries, or to generalise the triggers, mechanisms and outcomes of resistance from below. This paper hopes to offer some insights into the divergence of affected villagers within a crop boom, and calls for a rethinking of the character of rural politics in less-than-democratic settings, like China. This study is based on an extensive set of primary data collected from three fieldwork trips (in spring 2014, 2015 and 2016), which included 180 in-depth interviews with key informants (including 11 governmental officials from different levels, 15 company employees, 2 university professors and 153 villagers) and 3 focus group discussions. Quantitative data on villagers' attitudes towards the expansion of eucalyptus plantations was also collected in four selected villages through 108 in-depth interviews, with the questionnaires serving as a checklist to guide the information collection using snowball sampling. ${ }^{8}$ My observations from both fieldwork and secondary data are also used to strengthen the analysis.

This paper is structured as follows: In the next section, I briefly introduce the rise of the ITP sector in China, and particularly in Guangxi. In section three, I discuss the framing about villagers' inclusion and exclusion. In section four, I provide a more comprehensive typology about villagers' inclusion and exclusion in the ITP sector. Based on this typology, I then analyze villagers' reaction towards the rise of the ITP sector and their corresponding political reactions. Finally, I highlight four points that are key to understanding the trajectory of political reactions from below.

\section{The rise of the ITP sector in China}

Despite its significant scale and social-economic-environmental impacts, the rise of the ITP sector has received comparatively less attention than other sectors (e.g. food, biofuels, mining) in current land grabbing literature. In the past two decades, the ITP sector has expanded rapidly all over the world - including in Southern China (Kröger 2014, Overbeek 2012). As shown in Figure 1, between 1975 and 2000, the acreage of eucalyptus plantations increased by about 3.5 times, from 43.2 to 148.8 thousand ha. By 2013, the area covered by eucalyptus had expanded eleven times to 1.65 million ha. To date, Guangxi has more than one-third of the fast-growing forests in all of China, and the largest eucalyptus area in the country.

\footnotetext{
${ }^{8}$ For a better understanding of the story behind the "hard data" collected during the interviews, my questions are not limited to the questions listed on the questionnaire. I also asked other questions according to the information provided by the interviewees.
} 


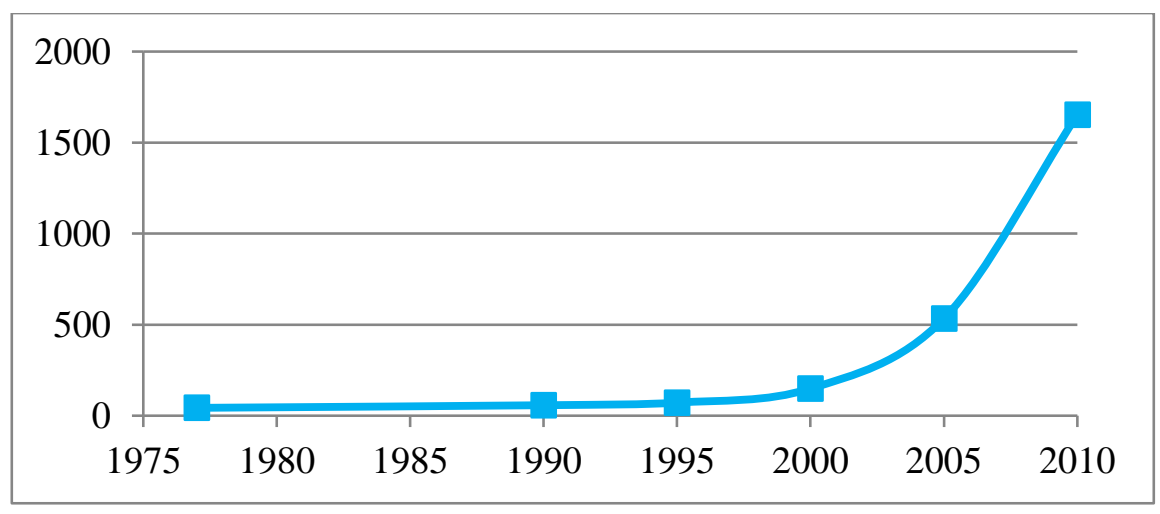

Figure 1 area of eucalyptus trees in Guangxi (1000 ha)

Source: 1977-2005 data (Pang (2006), 2010 data (Wei (2011).

These ITPs are of various scales and are operated by different planters/investors, ranging from transnational paper companies, Chinese state-owned forest farms, domestic private companies, individual entrepreneurs, and independent planters. Among the planters/investors in the ITP sector in Guangxi, two foreign investors, Stora Enso from Finland and Asia Pulp and Paper (APP) from Indonesia, have received much public attention, especially in the context of their acquisition of a combined acreage of about 200,000 ha.by 2015 (Liu 2010, StoraEnso 2016). It is important to address key impacts on rural communities.

Firstly, the rise of the ITP sector leads to significant changes in land systems in Guangxi in terms of land-use and land control, in both farmland and forestland. Before the cultivation of eucalyptus trees, farmland plots were originally used for food production (e.g. sugarcane and cassava). Less hilly and rocky forestland plots were previously used for grain and sugarcane cultivation (Li 2008, 27), while the non-arable forestland plots in Guangxi was mostly remain degraded, with pine trees or acacia trees planted dispersedly. ${ }^{9}$ The land control change linked to the ITP sector does not commonly emerge in farmland in Guangxi, as most of the farmland plots were fragmented when contracted to households during the Household Responsibility System (HRS) in the 1980s. However, the forestland owned by the collectives has a different story. ${ }^{10}$ Facilitated by the local government, the collective-owned forestland was (sub-)leased to investors, including foreign companies, domestic private companies, state-owned farms and individuals. Meanwhile, some of the forestland plots originally controlled by villagers, either via the HRS reform or customary occupation, were transferred to investors through lease or cooperation deals. This shows a far more complicated dynamic than the rise of the ITP sector in other regions worldwide. The Chinese case involves large-scale land acquisition by corporations (including a combined 200,000 ha total by two foreign companies), but without displacement of rural dwellers, in contrast to various cases elsewhere like in Brazil (Kröger 2012), Uganda (Lyons and Westoby 2014), and Ecuador (Gerber and Veuthey 2010). ${ }^{11}$ Meanwhile, it includes small-scale cultivation of eucalyptus trees as the case of Vietnam (Sikor 2012) and Thailand (Carriere and Lohmann 1996), and large-scale but individually-owned plantations also exist.

\footnotetext{
${ }^{9}$ These trees are planted by production teams rather than individual villagers. Villagers are not actively involved in planting trees to restore the collecively-owned forestland. It is mainly because that they are lacking economic incentives to plant pine trees or acacia trees and in shortage of money.

${ }^{10}$ In Guangxi, state forest farms own $10 \%$ of the forestland, leaving $90 \%$ in the hands of collectives. Collectiveowned land refers to the land owned by rural collectives (everyone in the community), which all of the villagers in the community can commonly use.

${ }^{11}$ It is linked with specific institutional arrangements in rural China. As mentioned by Ho and Spoor (2006), without a clear assignment of property rights and with the state's ultimate control, Chinese land system is proven to be secure and successful.
} 
Secondly, eucalyptus tree plantations are an attractive investment, considering their fast economic return, low labour costs and current domestic demands for raw materials (e.g. paper, wood-based board) in China. As commented by a villager, "planting eucalyptus trees is like (constructing) a bank there". ${ }^{12}$ Thus, the expansion of the ITP sector can bring great monetary profits. Thirdly, the ITP sector has significant negative effects on local ecologies. The ITP sector has high water and soil nutrition demands (Calder et al. 1997, Calder 2003). Local people always complain that ITPs are "water pumps" and "nutrition pumps", due to their negative effects on local hydrological and soil conditions (Carriere, Lohmann, and Lohmann 1996, Gerber 2011). Additionally, the industrial production mode and the chemical fertilizers and herbicides used, aggravate environmental and ecological damage. These environmental impacts are believed to be a prominent cause of resistance against the sector (Gerber 2011, Gerber and Veuthey 2010).

A few of these impacts on local communities in Guangxi (especially the environmental aspect), also occurred in some other regions during the expansion of the ITP sector, due to the particular features of the sector itself. However, the trajectories of political reactions from below can vary. In my fieldwork I found that quite a few villagers in Guangxi expressed their support of the development of the ITP sector. This differs from the argument in many studies from other countries that most villagers resist against ITPs, or at least have opposition to the expansion of the sector (Gerber 2011, Gerber and Veuthey 2010, Kröger 2013).

\section{Rethinking the dichotomy of villagers' inclusion and exclusion}

With the expansion of the ITP sector, some of the villagers became incorporated when they started to plant eucalyptus trees on their land. Yet, some of the villagers were excluded, similar to the observations by Hall et al. $(2011,13)$ that pointed out that "the inclusion of some land uses, and some land users, necessarily means the exclusion of others". In this paper, following the definition of 'exclusion' by Hall et al. (2011, 7), exclusion in the ITP sector refers to the situation of some villagers who are not able to benefit from planting eucalyptus trees. In this sense, villagers who are excluded are those who do not plant eucalyptus trees, either because they do not have access to the land and capital required, or because they do not have interest in planting eucalyptus trees due to access to other gainful livelihood alternatives. ${ }^{13}$ Thus, villagers who are excluded from the ITP sector are not automatically on the losing side. As one villager I interviewed in Xiangzhou County, who is involved in a transportation business described: "[our household] does not plant eucalyptus trees. [Because] it is very hard work to farm [the trees], and it did not bring money". ${ }^{14}$ In comparison, villagers who are included are those who can directly benefit from the ITP sector, including the owners of large-scale ITPs, independent planters, out growers, planation workers and landlords. In some cases, although the villagers can get income from the ITP sector via land rent or employment, such small benefits cannot compensate for their losses. ${ }^{15}$ As shown in Table 1, among the 104 villagers I interviewed, 80 villagers are included in the ITP sector, while the other 24 are not. Those who are included have a slightly favourable perception than those excluded (3.04 versus 2.67) on the economic value of planting eucalyptus trees. The difference is not that significant. ${ }^{16}$

\footnotetext{
${ }^{12}$ Field notes, $6^{\text {th }}$ Mar 2015

${ }^{13}$ Those villagers who are only involved in the upstream/downstream business and are not engaging directly in the ITP sector are also part of the excluded group.

${ }^{14}$ Field notes, $23^{\text {rd }}$ Feb 2016

${ }^{15}$ For example, the loss of control of the land they originally used, and the crop yield losses caused by the negative impacts of the ITP sector.

16 Only when $\mathrm{p}<0.05$, it means the difference is significant.
} 
Table 1 Villagers perception of the economic value of ITP sector

\begin{tabular}{lccc}
\hline & $\mathbf{N}$ & Means & Sig \\
\hline Included & 80 & 3,04 & 0,77 \\
Excluded & 24 & 2,67 & \\
\hline interviews, 2016; $1=$ very low economic value, 5=very high economic value. ${ }^{17}$
\end{tabular}

This complicated phenomenon reminds us to go beyond the simple dichotomy of "exclusion versus inclusion". Instead, to understand villagers' actual position within the value chain, attention should be paid to (i) the terms of inclusion and (ii) access to alternative livelihood opportunities. For those who are included, the terms and conditions of the inclusion, especially villagers' vertical and horizontal links within the value chain, can lead to completely divergent outcomes (Du Toit 2004). When linked vertically, villagers' autonomy and capacity are related to their access to diverse resources (e.g. land, labour, financial and social resources) and the degree of dependency on upstream (e.g. agricultural inputs companies) and downstream actors (e.g. processing mills, retailers). When villagers control abundant resources (including both material and social resources), or even engage with the upstream or downstream sector at the same time (e.g. selling seedlings, processing or trading timbers), they have more bargaining power, and presumably are able to benefit more than their counterparts (see also Hall 2011, 844). When villagers control limited means of production, or are constrained by monopolized channels for accessing agricultural inputs and selling products, they are very likely to be adversely incorporated. This means they are squeezed by the upstream and downstream market, and with limited or no control over the processes of production and output, as seen in the case of "productive exclusion" in Bolivia (McKay and Colque 2016). Underlying the above scenario, villagers are sometimes left more vulnerable than they were before their enrollment into the scheme (McCarthy 2010).

Horizontally, villagers' capacity to survive or compete with large corporations in the market is also directly linked to villagers' social differentiation. Such capacity is not only determined by villagers' agency per se, but is also influenced by the intervention of the state. When the state particularly favors large-scale investors, smallholders might become vulnerable and easily go bankrupt, as in the case of Ukraine (Mamonova 2015). ${ }^{18}$ When the state supports smallholders, some villagers might be able to prosper, as demonstrated in the case of Vietnam (Sikor 2012). In China, Zhang (2012, 474) found that, "strong state support for agriculture and for market development has created competing paths of agrarian transition based on independent household commodity production".

Another key issue relevant to both excluded and included villagers is whether they have access to alternative livelihood sources. In some countries, villagers' livelihoods are highly diverse, ranging from farm work to non-farm jobs. For those who have better alternatives, the exclusion from a crop boom does not bring any loss. This is particularly true in China, where farmland is relatively equitably distributed (the size of farmland is partly based on the size of

\footnotetext{
${ }^{17}$ The question is: Do you agree that the income of the villagers has been increased with the rise of the ITP sector? And the choices are 1: strongly disagree; 2: disagree; 3: Neither agree nor disagree; 4: agree; 5: strongly disagree.

${ }^{18}$ In Ukraine, the largest share of direct and indirect agricultural subsidies is given to the large agribusinesses, while private family farmers and rural households operate with nearly no state support. Besides that, private family farmers have to compete with large agribusiness for access to land and associated resources (e.g. grain storage facilities), which makes then financially disadvantaged, as they are unable to pay the market price for use of those resources.
} 
each household). Villagers' landholdings are usually tiny and fragmented, which brings little (but relatively equitable) agricultural incomes. In this sense, "the primary source of rural inequality is access to non-farm incomes" (Zhang 2012, 469). This is similar to what was indicated by Chen Xiwen, the Deputy Chief of Office of Central Rural Work Leading Group (CPC): "if only farming 6 or $7 \mathrm{mu}^{19}$ land for food production, the annual income is almost equal to the wage obtained in one month for doing migrant work in the urban area” (Guo and Tong 2015).

\section{Villagers' positions within the expansion of the ITP sector}

For a better understanding of how the expansion of the ITP sector impacts different villagers and their responses, this paper provides a more complex typology of inclusion and exclusion, which covers 'active inclusion,' 'passive inclusion,' 'active exclusion' and 'passive exclusion' (see Figure 2). Within this typology, villagers' control over means of production, production process and outputs, and their access to alternative livelihood sources are also taken into consideration. Those with limited/no control and limited/no access to alternative sources of incomes, villagers' inclusion and exclusion are considered 'passive' in my typology (Type B and Type $\mathrm{C}$, respectively). When villagers have sufficient control over means of production, production process and outputs, and even gain control over upstream and/or downstream businesses in a few cases, their inclusion is what I consider here as 'active' (Type A). For those who control enough means of production and/or have access to alternative sources of income, their exclusion is an active choice (Type D).

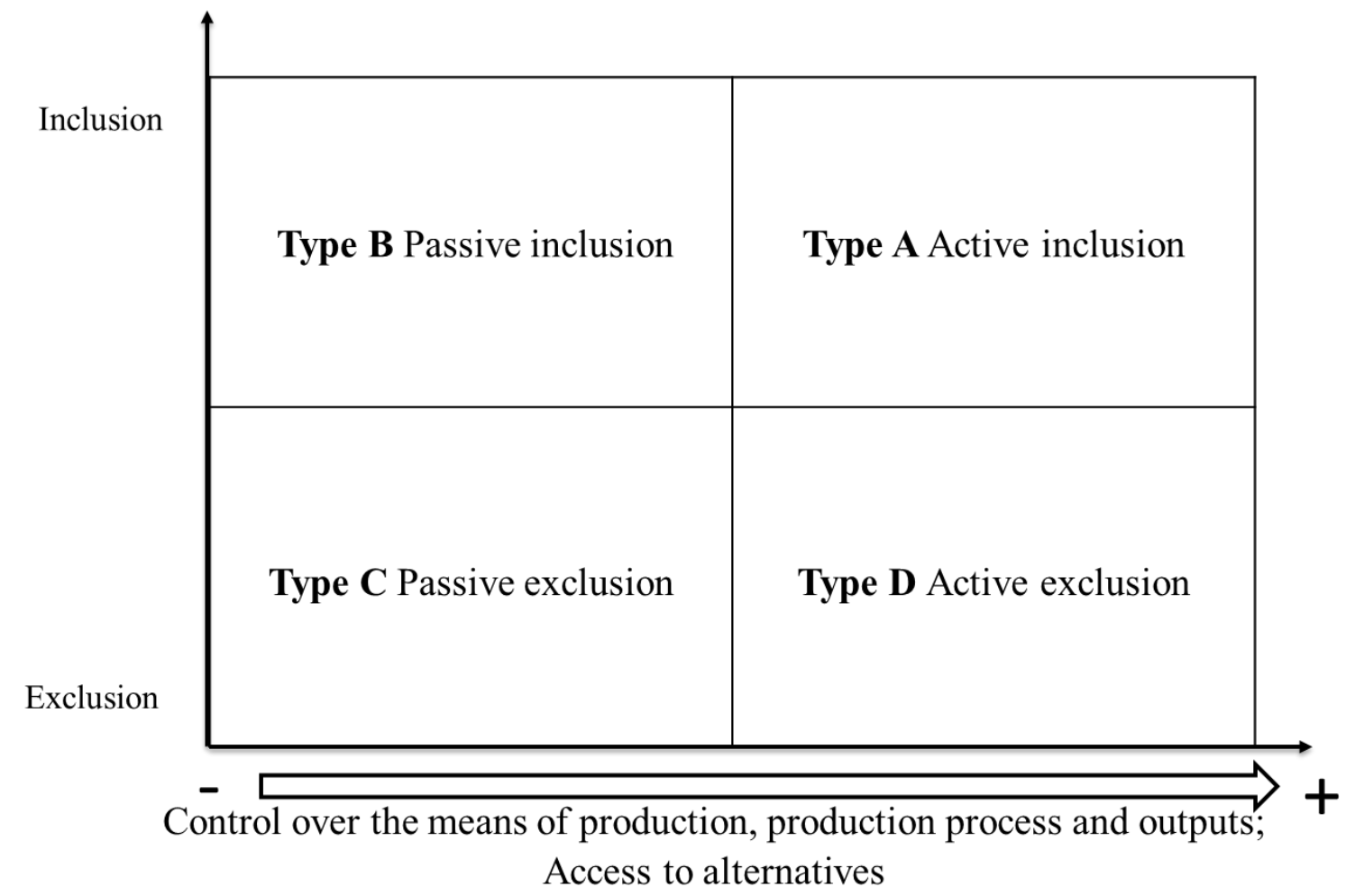

Figure 2: typology of villagers' positions

\subsection{Active inclusion}

Faced with the rapid expansion of the ITP sector, some villagers seized the opportunity and got incorporated into the sector. This group of villagers is located in a relatively

${ }^{19}$ It refers to a unit for the measurement of land - 15 mu equals 1 hectare. 
advantageous position within the value chain, because (1) they usually get control over sufficient means of production and (at least part of) the production process, and (2) some of them even became involved in upstream and downstream business. Regarding the means of production, due to favorable geographic conditions, customary occupation, and individual land leasing, some households do control more land resources. Firstly, due to various land resource endowments among villages in terms of quantity and quality, under HRS reform, land (mainly farmland) distribution is relatively equitable within the village, ${ }^{20}$ but it is not always the case between villages. Thus, in some villages, there is more land available to be allocated to villagers. Secondly, except for the distribution based on the size of households, there are also informal distribution schemes based on customary arrangements, mainly for the undistributed forestland. Those households with abundant labour and money, sometimes even with particular social capital (e.g. being village cadres), are able to gain access to more land. Thirdly, motivated by the rise of the ITP sector, some villagers leased large-scale forestland from their own or nearby villages with the financial and/or social capital they possessed. One villager in Wuming County, who contracted $30 \mathrm{mu}$ of land from his own village collective, explained: "when the Gaofeng state-owned farm came (to lease forestland in my village), some villagers and I also asked to contract (forestland) with the same term (30 years) and same rent (6 Yuan per mu per year)". ${ }^{21}$

Among these land-abundant villagers, some started to plant eucalyptus trees independently. These villagers are able to control the whole process of production and the sale of outputs. They decide whether to employ labourers or use household labour for sowing, weeding, fertilising and logging; they choose how to produce eucalyptus trees, either with intensive, little or no chemical inputs; and they make decisions on when and how to harvest, either to log and transport the products to the highest bidder or to sell the trees directly to middlemen. When competing with capital intensive investors (e.g. international corporations and stateowned farms), these independent planters are not in a disadvantageous position, and are unlikely to be excluded as in comparable cases in Ukraine (Mamonova 2015). It is mainly because of (i) certain features of the sector, (ii) the role of the state, and (iii) the market conditions of its outputs.

Firstly, high technological and machinery inputs are not necessary for the ITP production. Especially for the hilly and rocky forestland plots, machines are almost useless during the production and logging process. In this sense, villagers who can (at least partly) exploit their household labour have comparable advantage over those capitalist investors who have to spend extra cost on employing labour. Secondly, the planters are at least partly supported by the state. According to state policies, villagers have the priority to lease collectively owned land in their own villages, ${ }^{22}$ and in some villages are provided with reforestation subsidies and free seedlings from the local government. ${ }^{23}$ Villagers are also usually monitored more loosely than big corporations (e.g. state-own farms and foreign companies) are. Although this is partly due to the difficulties of monitoring individuals, this is also sometimes done intentionally by the Chinese state in order to maintain social stability (as will be analysed below). At times, villagers plant eucalyptus trees on farmland where the provincial government has forbidden it, but they are rarely penalized. Thirdly, the market for the outputs

20 Except for a small part of the hilly land already allocated through the HRS reform, most of the forestland remained in the hands of collectives.

${ }^{21}$ Field notes, $18^{\text {th }}$ March 2016

22 Although in some villages, a large part of their collective forestland has already been contracted out before they are motivated to invest in forestland.

${ }^{23}$ Under the Returning Farmland to Forest Program, planters got 210 yuan per mu per year for five years (as commercial forests) or eight years (as ecological forests). In 2007, the central state prolonged the subsidies for another five or eight years at reduced rates of 125 yuan (Zinda et al. 2017). The subsidies and free seedlings increased the economic incentives for villagers in Guangxi to plant eucalyptus trees. 
of the ITP sector is not completely controlled by few companies despite the towering presence of the world's top two ITP transnational companies (Stora Enso and APP), but involves diverse buyers, including different middlemen, timber processing mills of different sizes and paper companies. In other words, villagers can freely sell their products to the highest bidder in a relatively competitive market. However, this does not mean villagers can control the market or are particularly favoured by the market. In reality, villagers are inevitably affected by the fluctuation of market prices. This was described by one villager who has planted 7 mu of eucalyptus trees:

The price of tree originally (at the beginning of 2016) is 600 Yuan (per ton) ${ }^{24}$. In July, (the price) dropped to around 400 Yuan. For each ton, (the price) of the tree decreased 200 Yuan. The market is ruthless. (I asked: "so is this the reason why you do not sell your trees, although they have grown for 6 years and been ready for logging?”). Yes! I am waiting for the price (to increase). ${ }^{25}$

However, the category of independent planters is not a homogenous entity. The majority of them switched land use in only part of their land plots, mostly the degraded forestland, into eucalyptus tree plantations. They are ITP smallholders, usually with a total area of less than $30 \mathrm{mu}$. Thus, although it is relatively small, they are able to realize net gain from the ITP sector, since, as one villager said, "it is better than leaving the land abandoned". ${ }^{26}$ Another villager interviewed pointed out that, "harvesting 8-10 mu (of eucalyptus trees) can bring big income as much as tens of thousand Yuan at one time”. ${ }^{27}$ For these small-scale independent planters, being included in the ITP sector actually diversified their livelihoods, with income from eucalyptus trees constituting like a 'bonus'.

A few others are big holders of eucalyptus tree plantations, who are called "Da hu". Compared with the smallholders mentioned above, they have a much larger scale of ITPs, which can reach as much as 500 mu, according to data obtained during my fieldwork. Correspondingly, their investment in the ITP sector is much more intensive, which means more potential profits as well as higher risks (especially in the coastal region where there are frequent typhoons in the summer). In addition, to strengthen their active inclusion, some of these villagers chose to get involved in one or more upstream or downstream businesses in the ITP sector, including selling seedlings, investing in mills for timber processing, transporting trees and timber and being middlemen (who purchase trees from other growers, harvest, and then trade the outputs). These people are able to gain more income by expanding their role in the value chain.

In short, the inclusion of this group of villagers is due to their own initiatives and their embeddedness in particular structural and institutional conditions (e.g. land allocation, quality of land and so on). By increasing their control over the means of production, production process and outputs, they are able to gain economically under the rise of the ITP sector in Guangxi.

\subsection{Passive inclusion}

Not all the villagers who are included in the ITP sector realized gains. There are some villagers who are incorporated but under unfavorable terms, because (1) they control little or no means of production, and (2) they have little or no alternative livelihood opportunities. Compared with the former group, these villagers have little land resources, due to either existing geographic disadvantages or due to recent changes in land control. Firstly, as mentioned above, in some villages, there is little farmland and little or no forestland available for distribution. Secondly, in some of the villages with abundant forestland, this land was

\footnotetext{
${ }^{24}$ It refers to Chinese currency - currently 1euro $=7.35$ yuan.

${ }^{25}$ Field notes, $16^{\text {th }}$ February 2016

${ }^{26}$ Field notes, $22^{\text {nd }}$ February 2016

${ }^{27}$ Field notes, $13^{\text {th }}$ March 2016
} 
already occupied by or contracted to other investors (including some of the individual villagers) before the 2008 forestland reform, ${ }^{28}$ leaving little or no forestland for other rural dwellers. In such leasing cases, villagers usually receive very little or even no land rent. ${ }^{29}$ Thirdly, some villagers are not originally short of land, but because of financial difficulties, transferred (part of) the plots they controlled to investors, either through cooperation or leasing. ${ }^{30}$ They usually have little bargaining power in such land transactions. Little control over the means of production does not necessarily lead to losses for villagers. Another key issue is that these villagers have no better alternative livelihoods, including off-farm work opportunities. In rural China, "households with off-farm income - either local wages or migrant remittances - tend to be better off” (Murphy 2002, 72). A similar comment from a villager in Guangxi highlights this situation as follows:

If a household does not have anyone to be migrant worker and earn money back, the income only from farming is almost nothing to cover the living expenses of the whole family. If a villager does not go to work outside and depends only on farming, (he /she) may not be able to support his/her child to go to school. Working outside can get you 200 Yuan per day. How much can one earn from farming? ${ }^{31}$

However, not everyone has the opportunity to do migrant work to earn extra money to support their family, especially considering the high cost of living in urban areas. Therefore, this group of villagers engaged in the ITP sector in different ways, but always in subordinate positions.

Some villagers supply the land they control for eucalyptus tree cultivation, while other investors (either individuals, state-owned enterprises, domestic private companies or international corporations) provide financial support to cover the expenses of seedlings, chemical inputs, and labour. As a result, these villagers get a negotiated share of the benefits, ${ }^{32}$ while losing part of their control over the production process and complete control of the outputs. They tend to derive less profit from the ITP sector, and sometimes they even have to face the rent arrears.

A few villagers leased their land to investors, even if they had already planted eucalyptus trees by themselves, to cover the shortage in family income or to avoid further investment on necessary infrastructures (e.g. to rebuild the road to be able to transport timber). ${ }^{33}$ For these villagers, they lose the control over, at least part of, their means of production in exchange for some land rent, which is usually rather tiny compared with the benefit of ITPs (which can bring at least 1000 Yuan per mu per year). A couple who leased their forestland to Stora Enso in Hepu County explained that, "how much forestland can be distributed for (we) two? We only get some 200 Yuan per year through leasing to Finnish Company. What is the use of 200 Yuan now? It can only buy several jin ${ }^{34}$ pork, not even afford one jin seafood”.${ }^{35}$ In this

\footnotetext{
${ }^{28}$ Most of the collective forestland was not contracted to rural households as the farmland in the HRS reform was, leaving the user rights vague until the forestland reform started in 2008. The user rights of the collective forestland were, then, formally distributed and verified, although most of the land had already been used or occupied by villagers or external investors before the reform.

${ }^{29}$ During my fieldwork in 2016, villagers in only one of seven villages mentioned they receive 100 yuan per year as rent for their collective land. Villagers in other villages either said they never hear about the land rent or mentioned land rent is left in the collective for public activities.

${ }^{30}$ There are also some villagers who transferred their land control as an active livelihood choice (e.g. those who migrated to urban areas), but they do not belong to this group.

${ }^{31}$ Field notes, 16th February 2016

${ }^{32}$ According to my interviews, the percentage ranges from $30 \%$ to $50 \%$.

${ }^{33}$ Fieldwork interviews, $20^{\text {th }}$ March 2015.

${ }^{34}$ Unit for the measurement of weight: 1 jin $=0.5 \mathrm{~kg}$.

${ }^{35}$ Field notes, $20^{\text {th }}$ March 2015
} 
sense, their inclusion into the ITP sector can hardly bring any significant economic gain to their household.

Some villagers have to shift some of their plots for eucalyptus cultivation because of the negative ecological impact of the ITPs planted nearby. According to one villager in Binyang County, "there is no other crop that can be grown beside the eucalyptus trees...So if you plant eucalyptus trees, I have to also follow the same change in land-use". ${ }^{36}$ For them, their tiny ITPs - usually less than $1 \mathrm{mu}$ - are too small to employ labourers to log and transport the limited outputs to processing millers or companies. Additionally, the small scale made it difficult to negotiate a good price with the middlemen who purchase the trees. Thus, their inclusion does not bring more gains than their original land-use.

Some villagers, mainly those young and strong, are incorporated into the ITP sector through employment opportunities provided by the investors, who leased their collectively-owned forestland. Since the ITP sector is a labour-saving enterprise, villagers' employment is usually temporal and seasonal, ranging from 4 to 90 days per year. ${ }^{37}$ Among these workers, some are able to do relatively skillful jobs (e.g. logging), which can earn them higher wages at around 150-200 Yuan per day. Some others can only do simple jobs (e.g. weeding and fertilizing), with a much lower wage at around 50-100 Yuan per day. For these villagers, their incorporation only brings them a bit of unstable income, while also creating a lot of losses. Their losses not only include their exclusion from access to previously commonly-owned forest produce (e.g. firewood), which contributed to their income, but also the reduction of their agricultural yields due to the ecological impacts of nearby eucalyptus tree plantations. In this case, the villagers were dispossessed and (partly) converted into workers but did not migrate to urban areas. In a way, this is similar to what Watts $(1994,81)$ describe as the 'disguised proletariats'.

In short, these villagers are included in the ITP sector in subordinated positions due to their limited/no control over the means of production or access to alternative opportunities. As a result, most of them do not gain significant benefits from the ITP sector, while some even become more vulnerable because of their incorporation.

\subsection{Passive exclusion}

Similar to the previous group, this group of villagers also control little means of production and limited possibility with alternative livelihoods. However, they are left in a worse situation since they are completely excluded from the ITP sector either because of lack of social capital or illness. In one of the villages I studied, the collectively owned land had been leased out to investors. Most of the villagers do not receive rent directly. The majority of them do not have financial or social resources to acquire forestland anywhere else to plant eucalyptus trees, and their allocated tiny farm plots are necessary for food production. With the rise of the ITP sector, villagers have no land available to plant eucalyptus. As expressed by a production team leader in that village: "at that time, we did not know that the price of the tree is so high. If we had known, we would have distributed the forestland to each household to plant trees by ourselves". ${ }^{38}$ Without temporary access to alternative off-farm jobs, these villagers are left in a vulnerable situation, as one villager described, "all the land (forestland) in the village has been contracted. Where can I find land to cultivate? Now I just stay at home. No work (referring to off-farm work) can be found". ${ }^{39}$ This resonates to the emblematic example of Tania Li's ( $\mathrm{Li} \mathrm{2011)} \mathrm{observation} \mathrm{that} \mathrm{"their} \mathrm{land} \mathrm{is} \mathrm{needed,} \mathrm{but} \mathrm{their} \mathrm{labour} \mathrm{is}$ not”.

\footnotetext{
${ }^{36}$ Field notes, 30 $0^{\text {th }}$ March 2015

${ }^{37}$ Interviews, 2016

${ }^{38}$ Field notes, $2^{\text {nd }}$ March 2016

${ }^{39}$ Field notes, $3^{\text {rd }}$ March 2016
} 
In addition to being excluded from the ITP sector, some villagers have lost their original income and been negatively impacted by the ITP sector due to the changes in land control and land use in their collectively-owned land. Firstly, such land control change tends to exclude some villagers who used to get some income from these plots, as illustrated in the case of a household interviewed in a village in Hepu County:

In the past, my household income came from farming and cutting firewood. We have no other income. The food we grow was not enough to eat (because the farmland is in shortage in this village), so we all depended on cutting firewood to buy food. Now no firewood can be obtained. Because the Finish Company plants eucalyptus trees here and there is no brushwood (to be picked as firewood). ${ }^{40}$

Secondly, land-use change affects nearby farming, because of the significant ecological impacts of the ITP sector. One villager interviewed explained that: "since planting of eucalyptus trees, the land almost has no water. No springs come out. Now here no matter what crops are planted, they do not grow" (Field work, $3^{\text {rd }}$ March 2016). Similarly, affected by the high water demand of eucalyptus trees, all of the 25 villagers interviewed either stopped cultivating paddy or reduced the cultivation of paddy from 2 rounds to 1 round per year on their tiny farm plots (usually less than 0,1 mu per person).

These villagers are completely excluded and not able to benefit from the ITP sector. Moreover, when they lack alternative livelihood sources, these villagers become even more vulnerable.

\subsection{Active exclusion}

Not all villagers excluded are as vulnerable as the above group. Some villagers do not plant eucalyptus as they have better alternatives given their abundant resources (material, financial and social). Some of them control sufficient means of production, but choose not to plant eucalyptus. Some villagers prefer sugarcane, while others use their land for fruit trees. Their choices are based on careful calculations about cost and benefit, as one village cadre explained:

In the countryside, the price of eucalyptus trees is not stable. The trees need 3, 4 and even 5 years to get us income; while sugarcane can bring income within one year. As to fruit trees, when the trees bear fruit after cultivating for 3 years, the products of one year can bring profit to compensate for those three years. And the trees can bear fruit every year later on. ${ }^{41}$

Some of the villagers might not have control over large landholdings, but have access to other profitable off-farm work, including upstream and downstream businesses connected to the ITP sector (e.g. trading, transportation or timber processing). For these villagers, although they only own tiny plots, they can still acquire enough land using their financial capital if they want to engage in the ITP sector. Thus, their exclusion from the ITP sector is due to their own calculation. A villager who did not plant eucalyptus, but who has a transport business, explains:

Farming is just to get enough food to eat. My household does not have any land, so small, not a big patch. If we plant eucalyptus, the trees will shade neighbour's crops. Neighbours who plant sugarcane will curse you, and do not agree with your cultivation of eucalyptus. And, farming makes much less money than work (refers to non-farm jobs). Working for one day can earn you as much income to buy two bags of rice. ${ }^{42}$

\footnotetext{
${ }^{40}$ Field notes, $3^{\text {rd }}$ March 2016

${ }^{41}$ Field notes, $17^{\text {th }}$ February 2016

${ }^{42}$ Field notes, $23^{\text {rd }}$ February 2016
} 
Thus, this group of villagers has the capability and autonomy to engage in the ITP sector. They choose to be actively excluded based on their own calculations. For them, although they do not benefit directly from the ITP sector per se and might also be affected by the negative ecological impacts of the ITP sector, they are not considered vulnerable, and some even might gain additional income with the rise of the ITP sector when they engage in the upstream/ downstream businesses (e.g. timber processing and timber transport business). Based on the typology above, villagers' attitudes towards the economic value of the ITP sector are reconsidered. As shown in Table 2, villagers who are actively included in the ITP sector have the most positive perception of the ITP sector, and those who are passively excluded have the lowest regard of the economic value of the sector. Meanwhile, villagers who are incorporated in a subordinated way have a lower opinion than those who are excluded out of their own willingness. The difference between their perceptions is significant. Villagers' different engagements with the ITP sector notably affect their perceptions about gains or losses associated with the expansion of the ITP sector. Villagers who control the production process and outputs of the ITP sector (Type A) believe they can gain from the ITP sector. In contrast villagers who are adversely incorporated into the ITP sector (Type B) do not think so. For those who are passively excluded from the ITP sector (Type C), most claim that they lose from the expansion of the trees, which is much more pessimistic than those who are excluded actively (Type D). The result is aligned with the qualitative analysis above.

Table 2 Different types of villagers' perception of the economic value of ITP sector

\begin{tabular}{lccc}
\hline & $\mathbf{N}$ & Means & Sig \\
\hline Type A: active inclusion & 66 & 3,121 & \\
Type B: passive inclusion & 14 & 2,643 & 0,045 \\
Type C: passive exclusion & 13 & 2,385 & \\
Type D: active exclusion & 11 & 3,000 & \\
\hline
\end{tabular}

Source: Interviews in 2016; 1 = very low economic value, 5 = very high economic value.

However, such a typology is not static: villagers who are actively included, might lease out their land (due to income emergencies) and shift their situation into passive inclusion; villagers who are temporarily hired in the ITPs might lose their work and become excluded; and villagers who are actively excluded might decide to get involved in the ITP sector, depending on a range of structural and institutional factors..

\section{Perceptions about fairness or justness by affected villagers}




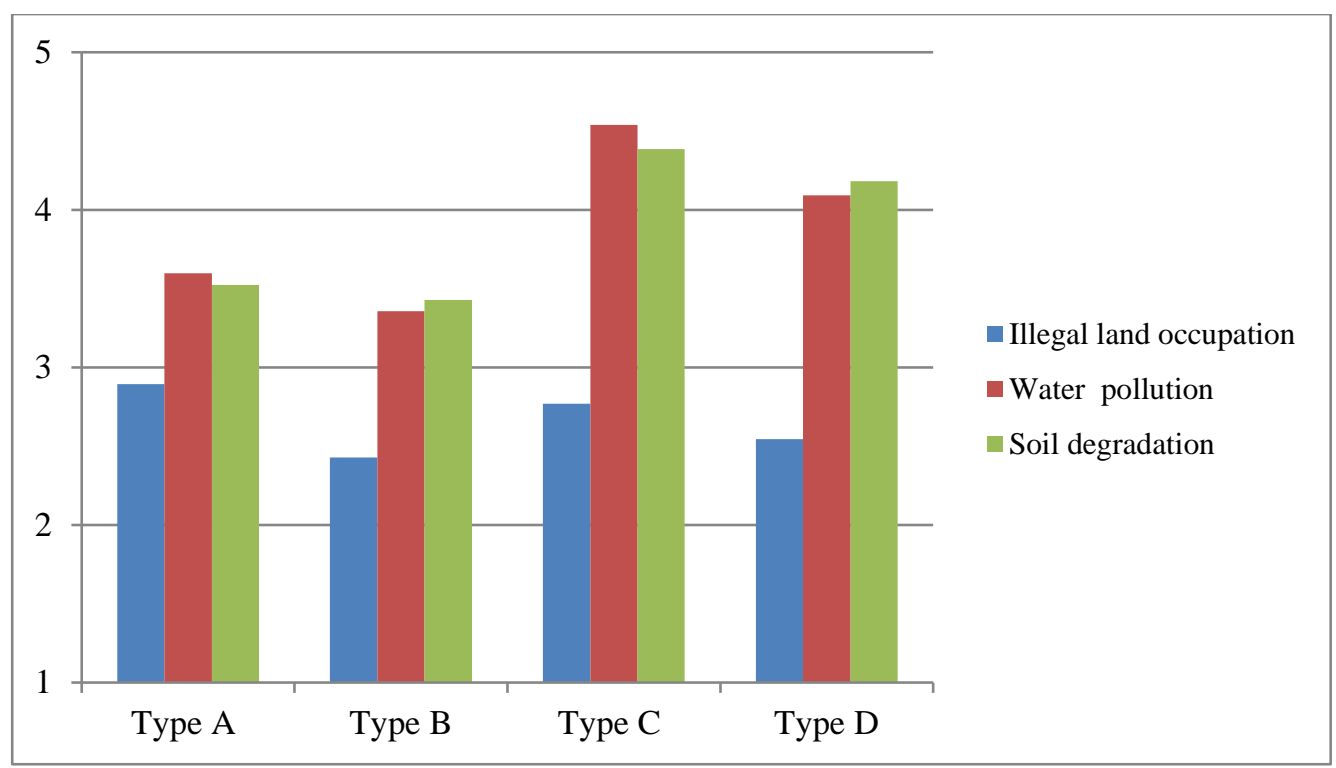

Figure 3 villagers' grievances towards land and environmental issues

Source: Interviews in 2016. 1 = low grievance level, 5 = high grievance level

As shown in Figure 3, villagers' perceptions of fairness or justness are concentrated on the environmental degradation caused by planting eucalyptus trees. The affected villagers complained that eucalyptus trees absorb too much soil nutrition and water, which will affect crops (e.g. sugarcane) planted nearby. Meanwhile, they also mentioned the negative ecological impacts on their livelihoods: "now the paddy is not able to be cultivated. Since the investors started to plant eucalyptus trees, here is very little water and becomes very dry. We can only plant some maize and peanuts. But (whether to harvest) still depends on weather". ${ }^{43}$ Some of the villagers are also worried about health problems caused by the ITPs. They claim that: "eucalyptus trees are poisonous. Now the water flowing down from mountains (where eucalyptus trees are planted) is all black". ${ }^{44}$ Among these villagers, those who are excluded (both actively and passively, type $\mathrm{C}$ and type $\mathrm{D}$ ) perceive unfairness on the grounds of environmental issues caused by the ITPs. With regard to land issues, villagers' perceptions of unfairness or unjustness were not significant (less than 3) during my fieldwork interviews. In the villages where collectively-owned forestland is allocated to each household, most of villagers claimed that land has been distributed to every household, therefore illegal land occupations have not occurred. Within this group of villagers, there exist some complaints about the shade of eucalyptus trees planted in the nearby farmland plots, which they believe is a kind of 'land occupation' and will affect their food production. While, in villages where forestland is distributed based on the principle of "first occupation" or customary occupation, some villagers complained that some elites are able to occupy more land due to better access to information. As explained by a villager during a focus group discussion:

In the past, here is undistributed waste hill...That one (refers to the ex-leader of the village) must know it (refers to information about the economic value of eucalyptus trees) from the county government. The (collectively-owned) forestland would have been distributed that year, but he occupied a lot of land himself. Other people around saw it. Then they also started to occupy the land. ${ }^{45}$

In the villages where collectively-owned forestland has been leased to outside investors, the villagers' concerns are more about land rent. According to a news report in Economy \&

\footnotetext{
${ }^{43}$ Field notes, $2^{\text {nd }}$ March 2016

${ }^{44}$ Field notes, $18^{\text {th }}$ February 2016

${ }^{45}$ Field notes, $11^{\text {th }}$ March 2016
} 
Nation Weekly, an employee from the Guangxi Forestry Department mentioned that the price of forestland in the province has increased more than 10 times since the land leasing started, so "there are huge conflicts" (Zhang 2010). While, among those who leased the land for planting eucalyptus trees, their complaints are usually about land encroachment onto their ITPs by local villagers. Among these villagers, those who are actively included (Type A), especially the owners of large-scale ITPs, resent what they preceive as illegal land occupations due to land encroachment by nearby villagers. In this situation, these planters complain about becoming the target of resistance from other villagers.

In short, villagers who are passively excluded (Type C) generally expressed perceptions of unfairness and unjustness towards the ITP sector, especially related to the environmental concerns. In contrast, villagers who are incorporated in the ITP sector have significantly fewer complaints about its negative ecological impacts. However, among these four types, the differences in villagers' attitudes towards land grabs caused by the ITP sector are not significant, partly due to their distinct understandings about 'land occupation'.

\section{Differentiated political reactions from the villagers}

Although almost every villager has some complaints against the ITP sector, not all of them have transformed their complaints into resistance. Some villagers support the expansion of ITPs, while some resist in either overt or covert ways. As summarized in Table 3, villagers who benefit from the ITP sector (Type A) generally embrace and even try to push the development of ITPs. For villagers who are adversely incorporated in the ITP sector (Type B), they do not show obvious opposition towards the sector itself, but engage in political struggles for the improvement of their inclusion (e.g. increasing the land rent). As the most vulnerable group, villagers who are passively excluded (Type C) tend to engage in resistance against the sector. Villagers of Type D mostly are indifferent towards the rise of ITPs, except in a few cases when they covertly resisted because their livelihoods were affected by negative ecological impacts.

Table 3 Villagers' different political reactions towards the rise of the ITP sector

\begin{tabular}{|c|c|c|c|c|c|}
\hline $\begin{array}{l}\text { Types of } \\
\text { villagers }\end{array}$ & $\begin{array}{l}\text { Gain or loss } \\
\text { within ITP } \\
\text { sector }\end{array}$ & $\begin{array}{c}\text { Political } \\
\text { behaviour }\end{array}$ & $\begin{array}{c}\text { For land } \\
\text { right }\end{array}$ & $\begin{array}{c}\text { For } \\
\text { environmental } \\
\text { justice }\end{array}$ & $\begin{array}{c}\text { For } \\
\text { economic } \\
\text { gain }\end{array}$ \\
\hline A & Benefits & Support & & & X \\
\hline B & $\begin{array}{c}\text { little benefit; } \\
\text { some even with } \\
\text { losses }\end{array}$ & Modification & $X$ & & $X$ \\
\hline $\mathbf{C}$ & Losses & $\begin{array}{l}\text { Resistance, } \\
\text { modification }\end{array}$ & $X$ & $X$ & $X$ \\
\hline D & $\begin{array}{l}\text { No losses; even } \\
\text { benefits }\end{array}$ & Indifference & & $\mathrm{X}$ & \\
\hline
\end{tabular}

Note: Summarized from the author's in-depth interviews and observations in Guangxi Specifically, for villagers of Type A, although most of them agreed that the ITP sector has negative ecological impacts, they still keep planting eucalyptus because "we farmers are practical (for making a living)" ${ }^{46}$ In a more extreme way, one villager in Xiangzhou County explained: "we farmers will run for where there exists the greatest profits. As long as it will not poison people immediately, we will plant what can bring the most money". ${ }^{47}$ In this sense, villagers' support for ITPs is out of their individual pursuit of profits. This group of villagers

\footnotetext{
${ }^{46}$ Field notes, 22 ${ }^{\text {nd }}$ February 2016

${ }^{47}$ Field notes, $17^{\text {th }}$ February 2016
} 
takes measures to secure and expand their control over it. To give an example: one villager who leased $200 \mathrm{mu}$ of forestland in another village to plant eucalyptus paid around 2000 Yuan per month to a local villager to protect his ITPs from being stolen or destroyed. ${ }^{48}$ In another case, a villager who already owned 150 mu of trees lent money to another planter enabling him to buy chemical inputs in exchange for the contract to purchase his trees at a certain price in four years. ${ }^{49}$

Villagers who are passively included (Type B) do not benefit much from the ITP sector. For them, their priority is to improve their terms of incorporation rather than resisting the ITPs' encroachment into their villages. As described by a villager in Hepu County, "we are poor. There is no other choice. [Leasing the land] can get some money, so we all want to lease the land out”. ${ }^{50}$ These villagers' actions are mainly against unpaid rent and underpaid labour in the ITPs ranging from overt litigation to covert pilfering and sabotage. Some of the actions are against investors, as is highlighted by the conflicts between villagers and StoraEnso discussed by Ping and Nielsen (2010). Similarly, according to the report of Economy \& Nation Weekly, in one village of Pubei County, villagers contracted their land to APP through the cooperation mode. They received no payment after two rounds of logging, so they denied APP's request to log again, as one villager in Pubei County explained, "Seedlings are from APP, but the land is mine. Why do they think they can log the trees when the price (of the land share) is not acceptable” (Zhang 2010). Some of these actions were also against other villagers, understood as the "poor-versus-poor" type of conflicts mentioned by Borras and Franco (2013). Such disputes are not only concentrated on the uneven access of land between rich and poor families, as one type of conflicts emerged in Vietnam (McElwee 2009, McElwee 2012), but are also related to the distribution of the benefits derived from plots with ambiguous land rights attached to them. One example is given by a villager in Hepu County: ${ }^{51}$

Villager: Here family X used to have a gang fight with family Y over a boundary of forestland which has already been leased out to Stora Enso. ${ }^{52}$

Author: For land rent?

Villager: Yes.

Author: But isn't the rent very little?

Villager: Even little, they still want it

For villagers who are passively excluded (Type C), they suffered the most from the expansion of the ITP sector. Their opposition is more significant. It can be encapsulated in the case of a village in Hepu County where a large number of villagers are passively excluded (as was mentioned during the analysis of passive exclusion). According to a villager interviewed:

In our village, all of the 10,000 ha eucalyptus trees have not been harvested... Like recently, the trees are all burnt down. It is burnt while there is only one year remaining before the trees are ready to be logged. Also, individuals tend to steal their trees. They (the thieves) are hardly caught. They steal the trees to sell... I do not know about the situation in other villages, but in our village, the bosses (refers to the investors of the ITP) have never harvested their trees. ${ }^{53}$

These villagers of Type $C$ resist the ITP sector through litigation, pilfering, arson, sabotage and land encroachment, which are in the forms of both overt "rightful resistance"(O'Brien et

\footnotetext{
${ }^{48}$ Field notes, $12^{\text {th }}$ March 2016

${ }^{49}$ Field notes, $18^{\text {th }}$ March 2015

${ }^{50}$ Field notes, $3^{\text {rd }}$ March 2016

${ }^{51}$ Field notes, $3^{\text {rd }}$ March 2016

52 Here I replaced villagers' family names with $\mathrm{X}$ and $\mathrm{Y}$.

${ }^{53}$ Field notes, $1^{\text {st }}$ March 2016
} 
al. 2006) and covert "everyday forms of peasant resistance” (Scott 2008). They engage in the struggles for two main reasons: First, their resistance can be understood as revenge for their livelihoods being undermined. Second, some of their actions are struggles for incorporation. To give some examples: encroaching onto the land acquired by large landowners enables the villagers to get access to some land to plant eucalyptus trees; stealing the tree is a way for villagers to share part (although very little) benefit from the ITP sector; and blocking the road is a strategy for villagers to get some compensation.

The villagers of Type D have alternative livelihoods. They seldom conduct any overt actions towards ITPs. As claimed by one villager, "the trees belong to Stora Enso. How does it have anything to do with us?”. ${ }^{54}$ However, there is some covert resistance for environmental justice, mainly done through the Internet. In few cases, however, they took more radical actions (e.g. subtle sabotage) when their livelihoods were impacted, as explained by a villager:

When planting eucalyptus trees too close, another villager will burn down trees, because the root of the eucalyptus tree will stretch towards where the sugarcane grows. Then, the nutrition will be extracted by eucalyptus trees, and trees will shelter the sunshine. For those households who plant eucalyptus trees in the middle of farmland and migrate out, their trees will be destroyed. ${ }^{55}$

In short, due to structural and institutional factors, the four types of villagers tend to take different reactions towards the expansion of the ITP sector. However, the cases outlined above do not intend to build automatic linkages between individual situations and a certain type of political reaction. In reality, villagers' political actions are the result of far more complex processes influenced by the political-economic context and individuals' own experience, interpretation, calculation and agency.

The scenarios described above are certainly not static, but change dynamically along with villagers' engagement and political opportunities. As mentioned above, villagers might change their position within or outside the ITP sector that in turn may alter their political calculation and action. This highlights how affected villagers will adjust their response strategies to the expansion of the ITP sector, along with social and institutional changes (e.g. policy changes and changing social relations). Villager's different political responses can partly (re)shape the social-economic structure in rural communities (including the actions of the investors and the state), which then in turn might influence villagers' engagement and political opportunity structure. Thus, this process becomes even more complicated.

\section{Further discussion on villagers' political actions}

Four key points emerge for developing a more comprehensive understanding of political reactions from below.

\subsection{The flexibility of the villagers' actions}

For those who resist against or struggle within the expansion of ITPs, we see diverse and flexible strategies. Villagers' weapons ranged from litigation to pilfering, arson, sabotage and land encroachment. Villagers typically avoid direct confrontation with powerful groups, making their resistance more tolerable to authorities. Additionally, as "leaderless and nebulous movements like Karen-style village resistance” (Malseed 2008, 504), most of the villagers' resistance in are spontaneous, adaptable and difficult to attack or co-opt. These features are explicit according to an employee of a state-owned farm:

Villagers who live near our forestland come and chop the trees (the state-farm planted). They sometimes even put some herbicide. Once the trees die, the villagers will occupy the land through growing some vegetables or sowing some hemp seeds.

\footnotetext{
${ }^{54}$ Field notes, $3^{\text {rd }}$ March 2016

${ }^{55}$ Field notes, $17^{\text {th }}$ February 2016
} 
Villagers encroach the land little by little every year...Villagers have time. Their land is just a few mu, and located where they can easily monitor. So no other people are able to occupy their land. ${ }^{56}$

Moreover, with the development of technology, villagers have an additional tool to facilitate their resistance, namely, the Internet. Most of the villagers currently have Internet access. Villagers are able to post their complaints on the Internet, such as through "Weibo" (the Chinese version of Twitter), or on a web forum. The anonymous feature of the Internet reduces the political cost of their resistance, and the prevalence of the Internet makes it easier to raise public concern and extend the reach of their political action in great speed. When a piece of news about illegal forestland expropriation is posted on Weibo (especially if there are photographs attached to prove it), it may be shared millions of times within a couple of minutes and soon get the public's attention, as well as that of the authorities.

\subsection{The role of the state}

It is important to address the role of the state in (re)shaping the villagers' political actions. The local government in particular is the target of a lot of the villagers' resistance more generally (So 2007). This is usually related to the state's role in facilitating land grabs, which might lead to the expulsion or dispossession of villagers. In the case of Guangxi, the state at the local level acts as a broker to help big investors (e.g. Stora Enso) get access to land to build ITPs. Moreover, state-owned farms and even some cadres (or their relatives) are directly involved in large-scale land acquisitions for ITPs. Thus, state actors (mainly local governments) are sometimes sued for illegal land expropriation. Furthermore, the state sometimes facilitates, and even supports, villagers' resistance. This is because of the dual function of the state. As explained by Fox (1993), the state has two contradictory tasks: to facilitate capital accumulation and maintain a minimum level of political legitimacy. This is also the case in Guangxi. As described by an employee from a state-owned farm:

Recently, villagers' land encroachment is very serious. To this illegal phenomenon, the government usually turns a blind eye... We used to catch villagers' (illegal behaviour) at the scene, and sued them. Then, the judgment is that the land belongs to the state-owned farm and is illegally occupied by villagers. The state (staff) said that this land plot is certainly belonging to ours, but (he or she) does not support us to get the land back, because the recapture with coercion will lead to resistance. Finally, villagers will go to the state for petitioning (shangfang) ${ }^{57}$. So (the land) is kept in the "bogged" status. The state just Da Tai Ji (which means to pass the buck). In normal time, (the state) says to support us, while finally, it has to consider the general interest. ${ }^{58}$

\subsection{Beyond the common assumption of: "villagers against foreign companies"}

In this paper, villagers' political reactions are much more diverse than the common assumption in the literature about: "villagers against foreign companies" scenario in current global land grabs. Firstly, villager's actions are not limited to "resistance”, but also include "support, compliance, modifications and evasions" (Kerkvliet 2009, 233). It is because villagers have different levels of control over the means of production, production process and outputs and varied access to alternative livelihoods. Secondly, foreign companies are not the only actors that the villagers resist against. As Borras and Franco (2012) argue, foreign capital is not the sole power that leads to large-scale land control changes. In the case of the ITP sector in Guangxi, domestic private companies, state-owned companies, individual entrepreneurs, the state and local elites all play a role in the expansion, either as direct land

\footnotetext{
${ }^{56}$ Field notes, $10^{\text {th }}$ March 2015

${ }^{57}$ It is a way for the citizens to petition higher levels of the state and express their demands.

${ }^{58}$ Field notes, $10^{\text {th }}$ March 2015
} 
recipients or indirect facilitators. Thus, they all might become the targets of the resistance when villagers' interests or even subsistence are seriously affected. Additionally, villagers' struggles are not only around land control and targeted at "grabbers", but are also related to the distribution of benefits among villagers. Thus, villagers sometimes also resist against their fellow villagers, highlighting that villagers' conflicts have more complicated contours. It could be "poor people versus corporate actors, poor people versus the state, and poor people versus poor people” (Borras and Franco 2013, Borras Jr, Franco, and Wang 2013, Hall et al. 2015). In sum, an over-simplified frame cannot capture the complicated trajectories of political reactions of villagers on the ground.

\subsection{Beyond land access}

In most of the literature about political reactions towards large-scale changes in land-use and land control, the focal points of contradictions are usually on land. My study shows that land is important but not the only determinant in villagers' politics. When villagers draw their income only from land, the conflicts are focused on the control of the land. In rural China, a large number of villagers get their income from non-agriculture sectors, rather than land per se (Ye, Wang, and Long 2009). For them, "farming income is just pocket money". ${ }^{59}$ Thus, with the expansion of ITPs, some conflicts are focused on the distribution of profits derived from the sector and protecting villagers' livelihood from being affected by the sector, rather than the land itself. To take the discussion a step further, villagers' concern is always centred on how to make ends meet or get more income. When land is villagers' primary source of income, they are more likely to take actions when they lose - or face the threat of losing control over their land. When their land provides very little income, villagers pay less attention to maintaining control over their land. During my fieldwork, several villages welcomed a land consolidation programme (called as "Shuang gao" or "Xiaokuai bian dakuai"). ${ }^{60}$ Some villagers were even eager to transfer their land control for rent, as was pointed out repeatedly by one villager from a village in Xiangzhou County where the programme has not yet been introduced: "after my land is expropriated (refers to joining the programme and leasing the land out), I started to have money". ${ }^{61}$ Villagers whose incomes are mainly derived from alternative off-farm work are less likely to resist against land control. If this group of villagers resists, it is usually covert and because of negative impacts on their livelihoods. Thus, to understand the complicated trajectory of political reactions within the large-scale land-use and land control changes, we must take into account the actual interests of different villagers as a unit of inquiry, rather than simply focusing on land access.

\section{Conclusion}

This paper has presented the dynamics of diverse political reactions from below, based on villagers' different linkages with changes in land-use and land control. It notes that varying interests and resource endowments (e.g. land, labour and social resources) differentiate villagers. Meanwhile, it considers the specific structural and institutional factors that these

\footnotetext{
${ }^{59}$ Field notes, $22^{\text {nd }}$ February 2016

${ }^{60}$ The project started from the land exchange among villagers within the community in Guangxi in 1996. At the beginning, such land consolidation was driven by the villagers spontaneously exchanging the fragmented land awarded in the HRS reform (as mentioned above) based on their social relations. Later, the state (referring to provincial and county government) became involved and soon became the driving force. The provincial government provided bonuses for villagers, rural cooperatives and companies who invested in the land levelling and infrastructure construction (including the road and irrigation construction), to encourage land consolidation from 2012. The county government helped the villagers/rural communities seek loans and firms specialised in land levelling/infrastructure construction to facilitate the project. According to document issued by the provincial government, the target area of the consolidated land in 2015 was 500,000 mu (equal to 33,333 ha) (see document from Guangxi Land and Resources Department 2012).

${ }^{61}$ Field notes, $21^{\text {st }}$ February 2016
} 
land-based changes are embedded in. This paper challenges the dichotomy of "exclusion versus inclusion", as it oversimplifies reality. The empirical data demonstrates that the terms of inclusion and villagers' access to alternative livelihood opportunities are closely related to the wins and losses of affected villagers. Based on these two factors, this paper offers a more complex typology: passive inclusion, active inclusion, passive exclusion and active exclusion. Following this nuanced typology, this paper analyzes the affected villagers' distinct positions within the ITP sector and their different political responses. This paper explores the divergence of villagers' political reactions, arguing that they are far more complicated than simply the "excluded villagers resisting against the expulsion/dispossession" scenario portrayed by recent land grabbing literature for three main reasons: (1) Villagers do not only resist against exclusion, but also struggle for better terms of incorporation and to reduce the negative impacts on their livelihoods; (2) Villagers are also resisting not only against land investors, but also other against villagers; and (3) Conflicts are not only about land, but are also about the distribution of social, economic and environmetal benefits and costs. To understand such dynamics, this study reveals the need for a systematic examination of villagers' actual interests in the context of land-use and land control changes based on their different positions within the value chain.

Acknowledgments: BRICS Initiatives for Critical Agrarian Studies (BICAS) with funds from Ford Foundation Beijing has supported part of my fieldwork in southern China. I am grateful to their support. I want to express my deepest thanks to Jun Borras, Max Spoor, Mindi Schneider, Natalia Mamonova, Tsegaye Moreda Shegro and Elyse Mills for their insightful inputs into this piece and/or earlier versions. I would also like to acknowledge the extremely critical but very constructive comments from anonymous reviewers that helped improved the quality of this paper. Any remaining errors are mine alone.

\section{References}

Alonso-Fradejas, A., 2015, Anything but a story foretold: multiple politics of resistance to the agrarian extractivist project in Guatemala. Journal of Peasant Studies, 42 (3-4), pp.489-515.

Borras, S. M, Franco, J. C. and Wang, C., 2013. The challenge of global governance of land grabbing: changing international agricultural context and competing political views and strategies. Globalizations, 10 (1), pp.161-179.

Borras, S. M., and Franco, J. C., 2012, Global Land Grabbing and Trajectories of Agrarian Change: A Preliminary Analysis. Journal of Agrarian Change, 12 (1), pp.34-59.

Borras, S. M., and Franco, J. C., 2013, Global Land Grabbing and Political Reactions 'From Below'. Third World Quarterly, 34 (9), pp.1723-1747.

Borras Jr, S.M., Franco, J.C., Gómez, S., Kay, C. and Spoor, M., 2012, Land grabbing in Latin America and the Caribbean. Journal of Peasant Studies, 39 (3-4), pp.845-872.

Brent, Z. W., 2015, Territorial restructuring and resistance in Argentina. Journal of Peasant Studies, 42 (3-4), pp.671-694.

Calder, I.R., 2003., 2 Eucalyptus, water and the environment. Eucalyptus: The Genus Eucalyptus, pp.36.

Calder, I. R, Rosier, P.T, Prasanna, K.T., and Parameswarappa, S., 1997, Eucalyptus water use greater than rainfall input-possible explanation from southern India. Hydrology and Earth System Sciences Discussions, 1 (2), pp.249-256. 
Carriere, R and Lohmann, L., 1996, Pulping the South: Industrial tree plantations and the world paper economy: Zed books.

Castellanos-Navarrete, A., and Jansen, K., 2015, Oil palm expansion without enclosure: smallholders and environmental narratives. Journal of Peasant Studies, 42 (3-4), pp.791-816.

Du Toit, A., 2004, 'Social exclusion' discourse and chronic poverty: A South African case study. Development and Change, 35 (5), pp.987-1010.

Edelman, M., 1999, Peasants against globalization: rural social movements in Costa Rica: Stanford University Press.

Fox, J., 1993, The politics of food in Mexico: State power and social mobilization: Cornell University Press.

Franco, J. C, Carranza, D. and Fernandez, J., 2011, New biofuel project in Isabela: boon or bane for local people. Agrarian Justice.

Gerber, J.F., 2011, Conflicts over industrial tree plantations in the South: Who, how and why? Global Environmental Change-Human and Policy Dimensions, 21 (1), pp.165-176.

Gerber, J.F., and Veuthey, S., 2010, Plantations, Resistance and the Greening of the Agrarian Question in Coastal Ecuador. Journal of Agrarian Change, 10 (4), pp.455-481.

Gingembre, M., 2015, Resistance or participation? Fighting against corporate land access amid political uncertainty in Madagascar. Journal of Peasant Studies,42 (3-4), pp.561-584.

Guo, X, and Tong, Z., 2015, Hanjun: Now most of Rural Household Earning the Same from Farming 1 ha of Land with Doing Migrant Work for One Year (韩俊：现在大部分 农户种一亩地赚的钱跟打工一星期差不多). People's Daily Online

Guangxi Land and Resources Department, 2012, Opinions about Encouraging Farmersinitiated Farmland Consolidation, accessed on $22^{\text {nd }}$ April 2016, http://www.gxdlr.gov.cn/News/NewsShow.aspx?NewsId=9595,

Guangxi Forestry Department,1998, Guangxi Tongzhi, accessed on 30 ${ }^{\text {th }}$ June 2016, http://www.gxdqw.com/bin/mse.exe?seachword=\&K=a\&A=46\&rec=86\&run=13

Hall, D., 2011, Land grabs, land control, and Southeast Asian crop booms. Journal of Peasant Studies, 38 (4), pp.837-857.

Hall, D., Hirsch, P. and Li, T.M., 2011, Powers of exclusion: Land dilemmas in Southeast Asia: NUS Press.

Hall, R., Edelman, M, Borras, S. M., Scoones, I, White, B, and Wolford,W., 2015, Resistance, acquiescence or incorporation? An introduction to land grabbing and political reactions 'from below'. Journal of Peasant Studies, 42 (3-4), pp.467-488.

Ho, P. and Spoor, M., 2006, Whose land? The political economy of land titling in transitional economies. Land use policy, 23(4), pp.580-587.

Kerkvliet, B. J. T., 2009, Everyday politics in peasant societies (and ours). Journal of Peasant Studies, 36 (1), pp.227-243.

Kröger, M. 2012. The Expansion of Industrial Tree Plantations and Dispossession in Brazil. Development and Change , 43 (4), pp.947-973.

Kröger, M., 2013, Grievances, agency and the absence of conflict: The new Suzano pulp investment in the Eastern Amazon. Forest policy and economics, 33, pp.28-35.

Kröger, M., 2014, The political economy of global tree plantation expansion: a review. Journal of Peasant Studies, 41 (2), pp.235-261.

Li, M., 2008, Dynamic studies about the Forest Rescource in Guangxi [Guangxi Senlin Ziyuan Dongtai Yanjiu], Guangxi University.

Li, T. M., 2011, Centering labor in the land grab debate. Journal of Peasant Studies, 38 (2), pp.281-298. 
Liu, Y., 2016, APP Guangxi Plantation-Pulp-Paper Integration Proejct 2010, accessed on 7th July 2016. http://finance.people.com.cn/GB/67723/67730/12680269.html.

Lyons, K. and Westoby, P., 2014, Carbon colonialism and the new land grab: Plantation forestry in Uganda and its livelihood impacts. Journal of Rural Studies, 36, pp.13-21.

Malseed, K., 2008, Where There Is No Movement: Local Resistance and the Potential for Solidarity. Journal of Agrarian Change, 8 (2-3), pp.489-514.

Mamonova, N., 2015, Resistance or adaptation? Ukrainian peasants' responses to large-scale land acquisitions. Journal of Peasant Studies, 42 (3-4), pp.607-634.

Martiniello, G., 2015, Social struggles in Uganda's Acholiland: understanding responses and resistance to Amuru sugar works. Journal of Peasant Studies, 42 (3-4), pp.653-669.

McAllister, K. E., 2015, Rubber, rights and resistance: the evolution of local struggles against a Chinese rubber concession in Northern Laos. Journal of Peasant Studies, 42 (3-4), pp.817-837.

McCarthy, J. F., 2010, Processes of inclusion and adverse incorporation: oil palm and agrarian change in Sumatra, Indonesia. Journal of Peasant Studies, 37 (4), pp.821-850.

McElwee, P., 2009, Reforesting "bare hills” in Vietnam: Social and environmental consequences of the 5 million hectare reforestation program. Ambio: A Journal of the Human Environment, 38 (6), pp.325-333.

McElwee, P., 2012, Payments for environmental services as neoliberal market-based forest conservation in Vietnam: Panacea or problem? Geoforum, 43 (3), pp.412-426.

McKay, B. and Colque, G., 2016, Bolivia's soy complex: the development of 'productive exclusion'. Journal of Peasant Studies, 43 (2), pp.583-610.

Moreda, T., 2015, Listening to their silence? The political reaction of affected communities to large-scale land acquisitions: insights from Ethiopia. Journal of Peasant Studies, 42 (3-4), pp.517-539.

Murphy, R., 2002, How migrant labor is changing rural China: Cambridge University Press.

O'Brien, K.J., Li, L., McAdam, D., Tarrow, S.G. and Tilly, C., 2006, Rightful resistance in rural China: Cambridge University Press Cambridge.

Overbeek W, Kröger M, Gerber J.F., 2012, An overview of industrial tree plantation conflicts in the global South.Conflicts, trends, and resistance struggles. In.EJOLT Report No. 3.

Paige, J.M., 1978, Agrarian revolution: Simon and Schuster.

Pang, Z., 2006, The General Development Status of Eucalyptus Tree Plantation in Guangxi Province.

Ping, L, and Nielsen, R., 2010, A Case Study on Large-Scale Forestland Acquisition in China. In The Stora Enso plantation project in Hepu County, Guangxi Province. Rights and Resources Initiative, Washington DC.

Rocheleau, D. E., 2015, Networked, rooted and territorial: green grabbing and resistance in Chiapas. Journal of Peasant Studies, 42 (3-4), pp.695-723.

Schneider, M., 2015, What, then, is a Chinese peasant? Nongmin discourses and agroindustrialization in contemporary China. Agriculture and Human Values, 32(2), pp.331-346

Scott, J. C., 2008, Weapons of the weak: Everyday forms of peasant resistance: yale university Press.

Sikor, T., 2012, Tree plantations, politics of possession and the absence of land grabs in Vietnam. Journal of Peasant Studies, 39 (3-4), pp.1077-1101.

So, A. Y., 2007, Peasant conflict and the local predatory state in the Chinese countryside. Journal of Peasant Studies, 34 (3-4), pp.560-581.

StoraEnso, 2016, Progress Book. In Stora Enso’s Annual Report 2015: Stora Enso. 
Watts, M. J., 1994, Life under contract: contract farming, agrarian restructuring, and flexible accumulation. Living under contract: contract farming and agrarian transformation in sub-Saharan Africa., pp.21-77.

Wei, J., 2011, The High Eucalyptus Trees and the Timber Production in Southern China (桉 树指天高产木看南国).

Wolford, W., Borras, S. M., Hall, R., Scoones, I. and White, B., 2013, Governing Global Land Deals: The Role of the State in the Rush for Land. Development and Change, 44 (2), pp.189-210.

Ye, J. Z., Wang, Y. H. and Long N., 2009, Farmer Initiatives and Livelihood Diversification, pp. From the Collective to a Market Economy in Rural China. Journal of Agrarian Change, 9 (2), pp.175-203.

Zhang, C., 2010, Eucalyptus Trees Enclosure Forestland (桉树圈林). Economy \& Nation Weekly (财经国家周刊).

Zhang, Q. F., 2012, The Political Economy of Contract Farming in China's Agrarian Transition. Journal of Agrarian Change, 12 (4), pp.460-483.

Zinda, J.A., Trac, C.J., Zhai, D. and Harrell, S., 2017, Dual-function forests in the returning farmland to forest program and the flexibility of environmental policy in China. Geoforum, 78, pp.119-132.

Yunan Xu is a PhD researcher at the Research Group, 'Political Economy of Resources, Environment and Population' at the International Institute of Social Studies (ISS), The Hague Netherlands. She has a fellowship from the China Scholarhip Council (CSC). She has published in Journal of Peasant Studies, Third World Thematics and Journal of Cleaner Production. Email address: xuyunancindy@gmail.com. 